\title{
Hierarchical Control of Intelligent Machines Applied to Space Station Telerobots
}

\author{
J.S. Albus, R. Lumia, and H. McCain \\ National Bureau of Standards \\ Gaithersburg, MD 20899
}

\section{ABstract}

A hierarchical architecture 1 described whicb supports spece station telezobots in a varlety of modes. The eysten is difided into three hierarchies: task decomposition, world sodel. and sensory procesaing. Goals at each level of the task decompostion hierarchy are divided both epatially and temporally into ainpler coanande for the next lower level. This decompoltion is repeated until, at the lowest level, the drive signals to the robot actuatore are generated. To accomplish lts goels. task decomposition modules must often use inforsation stored in the vorld model. The purpose of the sensory systen is to update the vorld nodel as rapldiy as poseible to keep tbe model in regiatration with the phyaical world. This paper desosthes the architecture of the entire control systen bierarchy ad hou it can be applifed to sace telerobot applicationa Ane f pate

\section{InTrODUCTION}

One of the najor directions on wich the robot research conanity has concentrated its efforts is concerned vith planning and controlling ootion. Given apecific task, a sotion plan wast be calculated which meeta the tak requirements. Then, the plan must be executed, there nust be sufficient control for the robot to edequately effect the desired notion.

Trajectories are often plenned as straight lines in Cartesian epace (1). Whitney (2,3) developed the resolved cotion rate control aethod for cartesian staight line notions: Paul $(4,5,6)$ used honogeneous coordinate transfornations to describe e trajectory as a function of tine, and raylor (7) used coordinated jolnt control orer anall segaents to keep the trajectory within a secified derlation of the desired straight ine trajectory.

While the researcb described above enploys "kinenatic" approach to robot control. another direction of research takes the manipulator aynanlcs" into account in the description of robot notion. The dynanic equations of notion are described elther by the Lagrangian formulation (8) or by the Mevton-Buler equations $(9)$. Algorithas and conputer architectures have been suggested which pronise real-tiae dyanic robot control (10,11).

Another aspect of notion control is concerned witb the variables being controlled. The reseerch described to this point was concerned prianily with position control. The robot moved $t$ zol an initial position to a goel position. while this is perbaps the most common node. there are cany applications for robots which uggest that other varlables should be controlled. For example. force control would be desired for assenbly operations. Maibert and Craig (12) suggest aethod tor bybrid position/force control of anipulatora.

These examples point to the nore generel probled of sensory processing. For great deal of robot motion research, sensory processing has been linted to joint positions. relocities, and accelerations. Howerer, otber sensors are often required to acconlish taks. The control conmunity has concentrated on the control aspects of the robot and as a resilt, lit:le enphasis has been placed on sophisticated sensory procesing.

Machine vision, an offshoot of inage proceseing reseerch, has recently been ascoclated with advanced robot applications. One of tbe nost interesting directions in this research area is concerned with sensor controlled robots. Operating ulth the constraints laposed by real-tlee robot control, early metbods used atructured light and binary lages $(13,14,15,16)$. These approaches, though dereloped at different institutions, mared any concepts. One of the inportent ubsequent researcb efforts vent tovard the developeent of nodel-based inage procesaing. Bolles and cain (17) used sodels of objects to guide the algorithas in a bypotbesis/rerificetion schene knovn as the local teature focus nethod. The concept bas recently been extended fron tro diensional (i.e. nearly flat) objects to three dimensional objects (18). Although the approaches described here have led to a better understanding of real-tine vision processing, the systens lacked a sophisticated interconnection with the robot control systes. 


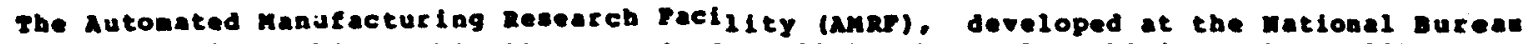
of standards, is a hierarchlcally organized seall-betch netal machining ahop (19). It eeparates ensory processing and robot control by a sopheteated world nodel. Fbe world nodel hes three conplenentary deta representations. Louta (20) describes the cab-ilke eection of the nodel. shneler. reat, and Mansbech (21) describe the octree and table representutione supported by the nodel. The nodel generates bypotheses for the featurea

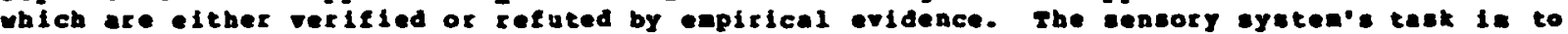
update the appropriate parta of the worid nodel vith nev or revised data as rapidiy ar possible. The control systes acceses the world nodel as desicd to obtain the cerrent best gues: concerning any aspect of the world. shneier. tonia. and rent (22) describe the

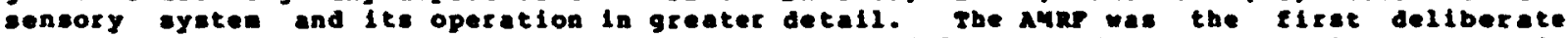
atteapt to tie together sensory proceseing, world nodeling, end robot control ia generic

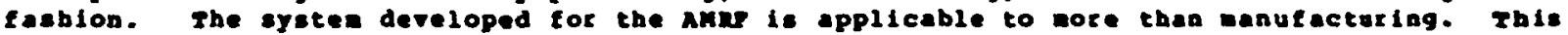
peper describes its use in epace telerobotics.

\section{A POWCTIOWAL STSTEM ARCaITECTURE}

The fundagental paradige la shoun in Figure l. The control sysee architecture is a three legged hiererchy of computing modules. eerviced by a comunicatione aysen and a comen aenory. The task decomposition eodules perfore real-tine planning and takt conitoring functions, and deconpose tagk goals botb epatially and teaporally. The sensory procesaing nodules filter, correlate, detect, and integrate censory infornation over both epace and time in order to recogalze and aeasure patterns. features. objects. erents. and relationshipe la the external vorld. The vorld nodeling nodules answer gueries, anke predictions. and coppute evaluetion functions on the state opace defined by the inforantion

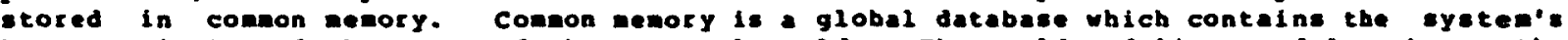
best evtinate of the state of the external vorld. The vorld modeling nodules keep the comeon nevory database current and consistent.

\subsection{Task Decomposition - a nodulea \\ (Plan. Execute)}

The firat leg of the hierarchy conslats of task decospostion a nodules which plan and execute the deconposition of higb level goals into lov level actions. Task deconposition involves both temporal decosposition (1nto sequential actione elong the tine line) and a spatial deconposition (into concurrent actions by different subeystens). Bach a nodule at each lerel contste of fob asigneent anager JA. a set of planners pL(1). and a set of executors $\mathrm{BX}(\mathrm{i})$. These decompose the input task into both spatially and tenporally distinct cubtaks as shown in Figure 2. Tbi will be deacribed la greater detall in ection 4 .

2.2. Wor 1d Hodeling - n sodules

(Reaember, Batiate, Predict, Braluate)

The second leg of the hierarchy consist of world aodeling n nodules which model (i.e.

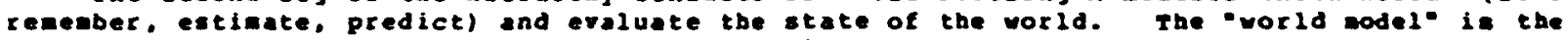
systen's best estinate and evaluation of tbe history, current state and possible future etates of the world, including the states of the system being controlied. The irorld model includes both the $M$ modules and a kowledge base atored in conon nemor databae where state vaciables, naps, lists of objects and events, and attributes of objects and events ate aintained. By this definition, the vorld nodel corresponds to vtat lo videly knous throughout the artificial intelligence coneunity as a blackboard (23). The world aodel perforas the collowing functions:

1. Maintain the conmon menory knouledge base by accepting infornation fron the sensory systen.

2. Provide predictions of expected sensory input to the cor:esponding aodules. based on the state of the task and estimates of the external vorld.

3. Answer What is? questions asked by the executors in the correspoading level nodules. The task executor can request the values of any systed variable.

4. Answer what if? questions asked by the plannera in the corresponding level I nodules. The n modules predict the results of bypothesized actions.

2.3. Sensory Processing - G nodules

(Filter. Integrate. Detect, neasure)

The third leg of the hierarchy consists of aensory processing G aodules. These recognize patterns, detect events. and filter and integrate sensory inforeation orer epace and tine. The G modules at each level coppare vorld model predictions with engory observations and conpute correlation and difference functions. These are integrated over

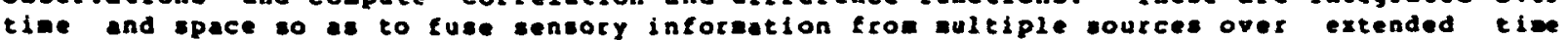


intervals. Wewly detected or recognised evente, objecte, and relationablpe are eatered by

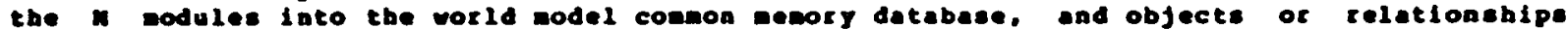
percelved to no longer exile are resored. The G nodules also contain functione which can compute confidence tactore and probabilitles of recognised events. and statistcal estinates of techatic etate varlable values.

\subsection{Operator Interfaces}

(Control. Observe, Deflae Goals. Indicate objects)

The control architecture defined here hes an operator Interfece ateach level in the biererchy. The operator interface provides a ceane by which huean operators, either in the space etation or on the ground, can obeerve and upervise the telerobot.

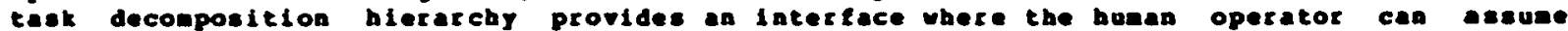
control. The task conends into ear letel can be derived elther froe the higher level eodule. or from the operator interfece. osing variety of input devices such a a foyetlck. souse, trackball, light pen, keyboard, rolce input, etc. a huan operator cap enter the control bierazchy at any level, at any tiae of his choosing. to nonitor a procese. to inert inforetion, co lacerrupt automatic operation and take control of the task being

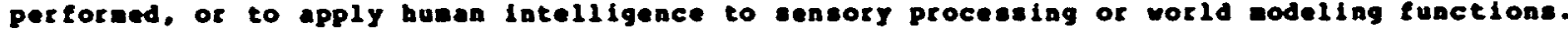

The shering of comeand input between huen and autononous control need not be all or none. It le posable in any cases for the hunan and the autonatic controller to ileultaneousy sbare control of a telerobot aysten. For exaple a buan might control the

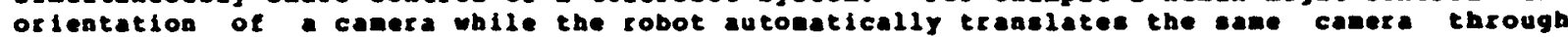
epace.

\subsubsection{Operator Control interface levele}

The operator can enter the hierarchy at any level. The operator control interface Interprets teleoperation in the fullesteenees a teleoperator is any device uhich le controlled by a huean from a remote location. while the mater-glave paradige is certalniy - type of teleoperation. It does aot conetitute the only form of an-inachine interaction. at different levele of the hierarcby the interfece device for the huean any change but the fundeental concept of teleoperation is etill preserved. zable 1 lilutiater the inceraction on operator ay have at each level.

The operator control interface thus provides echanises for entering new instructiona or prograes into the various control nodules. This can oe ubed on-line for real-tiae supervisory control. or in a background node for altering autonomout telorob plane before autononous execution reaches that part of the plas.

\subsubsection{Operator monitoring interfaces}

The operator interfaces allov the buman the option of seply anitoriag any leve:

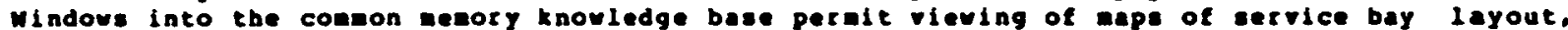
geoetric description. and pechenical and electrical configuration of eatelities. 11 ete of recognized objects and everts, object paraceters. and state variables such a positions. relocities, forces, confidence levels, tolerances, traces of past history. plans for future actions. and current priorities and utility function ralues. rhese ay be displayed ln graphical fore. for exaple using dials or bar graphs for ecalar variablea. abaded grapblcs for object geonetry. and rariety of ap displays for apatial occupancy.

\section{4 .3 seneory proceseing/rorld podeling interfaces}

The operator interface ay also permit interaction with the sensory prcceselng andor world bodeling codules. For example. an operator using a ideo monitor with a graphice overlay and a light pen or joystickeight provide buen interpretative aselstace to the vision/world nodeling systea. The operator aight interactively asist the aodel natching algorithes by indicating with light pen which fectures in the inage (e.g. edges. corners) correspond to those in a tored nodel. alternatively. an operator could use joystick to

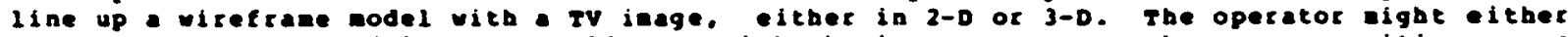
move the wirefrae nodel so a to line up uith the inage, or nove tbe caera position eo a to Iine up the lage wth the odel. Once the alignment was nearly correct. the operator could allor automatic atching algorithes to conplete the eatch. and tiack future novenents of the inege.

\subsection{Connon Menory}

\subsubsection{Conenications}

One of the prinary functions of conon nesory is to facilitate coneunicatione betreen godules. Coneunications within the control hierarchy le supported by a conon etery in whicb stete reriables are globally defined. 
Each wodule in the ensory proceseing, vorid modeling, and tesk decomposition hlerarchies reads lapete fron, and writes outputa to, the comon nemory. Thus cech module

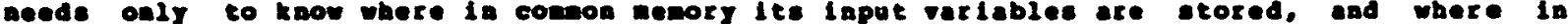
connon mesory it abould urlte lts output varlebles. The data etructures in the comon

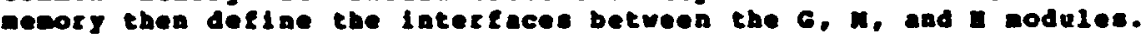

The operator interfaces also interact with the eyeten throng conon nenory. The operator aleplaje elaply read the variables they need from the locatione in conson nemory. If the operator ulates to take control of the oyoten, he oloply wites comand variablea to the eppropilete locetions in connon nemory. The control modules that read fros those

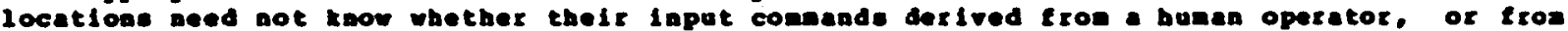
the next algher level in the antononous control hlerarchy.

\section{5 .2 state Veriables}

The etate variables in conon eesory are the systed's best estinate of the ctate of the

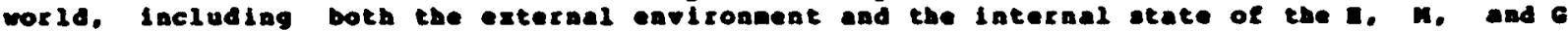
nodules. Date in compo nemory are avallable to all modules at all levele of the control ersten.

Tbe knovledge base ia the comon nenory consists of three elenentse maps whicb describe tae epatiel occupacy of the world, object-ettribute linked lises, end etate verlables.

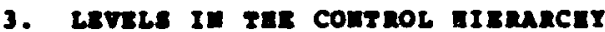

The control systen axchitecture descrlbed bere for the Filgbt relerobot syaten is a sx

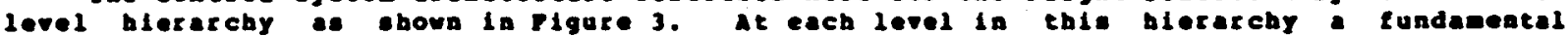
transfornation is pertorned on the takk.

hevel 1 traneforas coordinates fros convenlent coordinate frese Into joint coordinates. rhis level also servos joint positions, relocities, and forces.

Level 2 conputer inertial dyanics, and generates smooth trajectorles la a convenient coordinate trane.

Level 3 deconposes elenentary cove connands (z-moves) into etrings of interaediate poses. F-mores are typlcally defined in terme of wotlon of the subeyeten belag controlled 11.-.. transpoter. anipulator, camere platform, etc.) through apece defined by

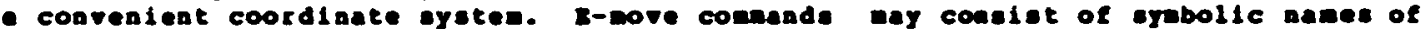
elementary novenents, or may be expressed as keyfreae descripelions of desired relationships to be ecbieved between eyeten state variables. I-soved are deconposed into strings of interiediate poses ubleb define notion pathvays that heve been checked for clearance with potantial obetacles, and ubleb avold hineatic eingularities.

Level decomposes object task connends specified in terme of actione pertoraed on objects into sequences of z-noves defined in teras of anipulator notions. object tesks typically define actione to be perforned by alngle multiaraed telerobot ereten on one object at tiae. Teaks defined in teras of actions on objecte are decomposed into sequences of s-moves defined in teras of eanipulator or vebicle subsyeter potions. This decopposition checks to assure that there exist motion ereevays cleer of obetecles between keyerene poese. and schedules coordinated ectivity of telerobot ubsystens, uch as the transporter, duel ara sabipulators, nutifingered grippers, and canera aras.

Level 5 decouposes ections to be performed on betches of parte into task perforaed on individual objects. It schedules the actions of one or nore telerobot aysenes to coordinate vith otber aechlnes ad syates operating in the lenediete vicinity. For example, hevel deconposes service bay action schedules into uguences of object taek consand to varlous telerobot servicers, atroanuts. and autonatic berthiag nechanisas. service bay actione are typlcally specified in termes of cervicing operatione to be performed by all the aystens (mechanicel and huan) in cervice bay on abole setelilte. This deconpostion eypically aesigne servicing task to varlous telerobot ejetens, ind -chedules serviclag tesks so a to maximize the effectivenes. of the mervice bay resources. 


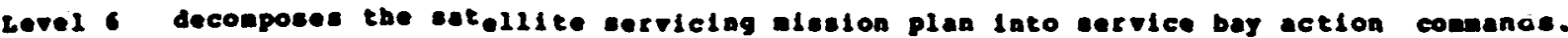

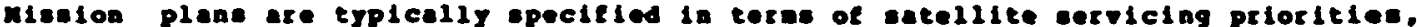

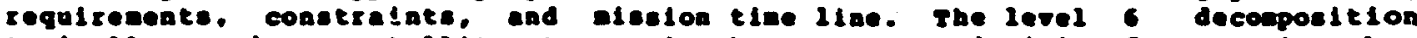
typlcally asigas sateliltes to service bays sete prloritles for aervice bay ectivities, generates requiremente for upare parte and tool kits, and schedules the activities of the service bey so as to eaxinize the effectirenes of the eatelilte cervicing aiseion. To a large extent the level s lission plans vill be generated ofl line on the ground, efther by buen wiselion planaers, or by autonatic or seniautonatic miseion planing aetbods.

\section{DETAILED STROCTORE OP THE a mODOLEs}

The I godule at each level consists of three perte ab bhown in rigure is a job

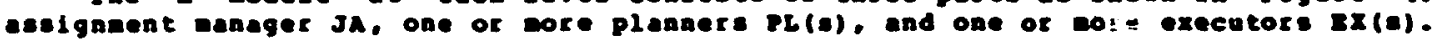

The job aseiganeat anager $J \lambda$ it responsible for pertitioning the task connand rC into - epatialiy or logically distinct jobe to be perforead by phyalcally distinct planner/executor mecbanlses. At the upper levels the job assignaent module may also assign phyeicel resources ageinat task elenents. The output of the job assignaent nanager is a set of job comande JC(s), s=1, 2, .... W where w is the nubber of epatielly. or logically. diselinet jobs.

Por each of these job comande JC(s). there existe planaer ph(a) and a executor Ex(a). Iacb planner pl(a) la reaponsible for decomposiag ita job conand JC(a) lato a

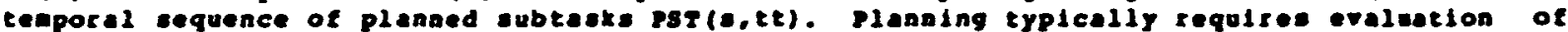
aternative bypothetical sequences of planned subtaks. The planner hypothesises sone action or series of actioas, the world nodel predicts the resulte of the action(a) and conputes sone evaluation Eunction EF(a,tt) on the predicted resulting tete of the vorld. The hypothetical sequence of actions producing the bestevaluation function gF(a,te)an is

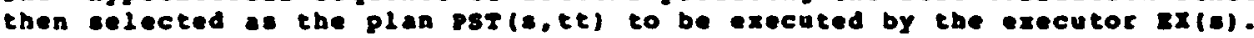

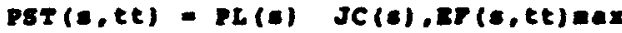

where te is the tine sequence index for stepe in the plen. tt ay also be defieed as a runaing tenporal index in planing spece. te $=1,2, \ldots$. th where th la the value of the te index ot the planning borizon. Tbe pleaning horison is defined ae tae period into the future over wich a plan ta prepared. Each level of the bierarchy bas a planning borison of one or two expected input takk tien durations.

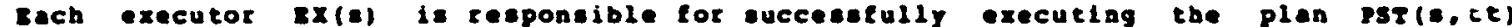
prepared by ite respective planner pl(a). It all the eubtask ia the plan pST(a,te) are accesafully executed, then tbe goal ct the original task uill be ecblered. The executor operates by selecting subtask fron the curcent queue of planned subtesks end outputeling a subcomand stx(s,t) to the approptiate subordinate a sodule et tiae $t$ ghe Ex(s) module monitore Its feedbeck PB(s,t) input in order to servo les output: $(s, t)$ to the desired subtank activity.

$$
\operatorname{sTx}(\varepsilon, t+n)=\operatorname{sx}(s) \quad \operatorname{PsT}(\varepsilon, t), \mathrm{PB}(s, t)
$$

where n - the nuaber of state clock periods required to conpute the function mx(s). n eypically equals 1. The teedback ro(s,t) elso cerrles tining and subgoel event information for coordination of output betreen executors at the eane level. When the executor detectse subgosl event, le selecta the next planged subtak fros the queue.

Bxecutor output stx $(s, t)$ aso contalns requents for information tron the rorid model n codule, and atetus reports to the next bigber $(1+1)$ lerel in the sodule hiterachy. The feedback pala,t) contains atatua reports fros the aodule at the i-1 th lerel indicating progress on its current task.

\section{5. concrusion}

This paper has described a hierarchically organized control oysee and has shoun hou this generic gyoten can be applied to telerobotic epplications in epace by considering the requirements of alight telerobotic eervicer for the epace et ation.

\section{expresters}

(1) M. Brady, et.el.. ed. Robot Motions planning and control. (Canbridge, nir preas. 19821 .

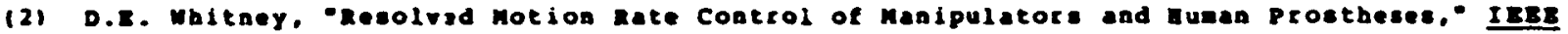
Trans. Man-Machlne sroteas mus-10, 1969. p. 47. 


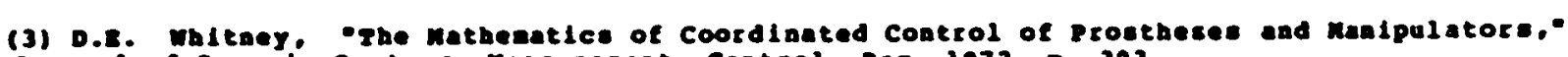
Journel of Draebic sxetebe, yeevereente Control. Dec. 1972. P. 303.

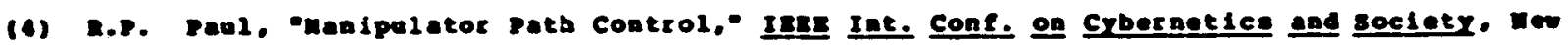
York. P. 147.

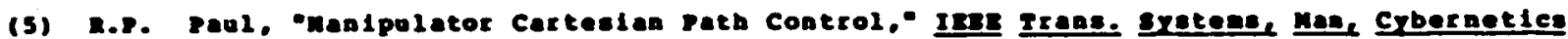
snc-s. 1979, p. 702.

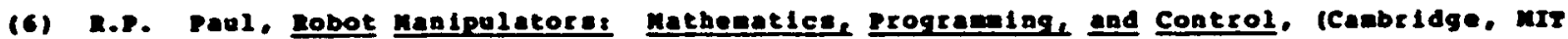
Prese. 1981.)

(7) R. I. Taylor, -planiag and Execution of straight-ilne manipulator rrajectoriea,- Ine J. Research and perelopent 23 1975. P. 124.

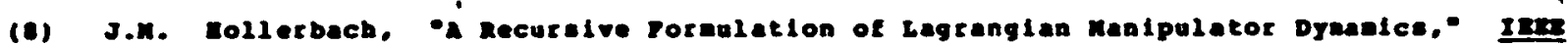

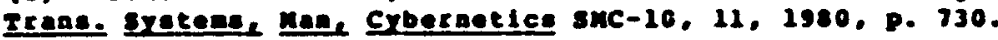

(9) J.Y.3. Lub, M.W. welker, and R.P.C. Paul. Oa-1lne Computational schene tor Mechanical Manipuletors." J. Drnanic sratens, Measurement, Control. 102, 1980. P. 69.

(10) C.s.G. Lee, P.R. Chang, Efflelent parallel algoritha lor lobot Inverse Dynanlea

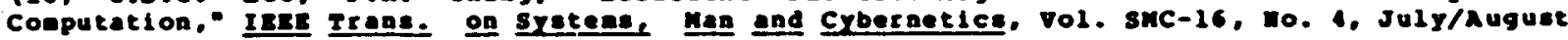
1906 . P. 532 .

(11) E.z. Dinder, J.M. Merzog, Distributed Conpeter architecture end Past Parellel

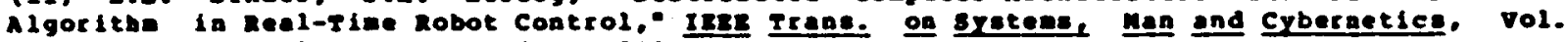
snc-16. Do. 4. July/august 1986, p. S43.

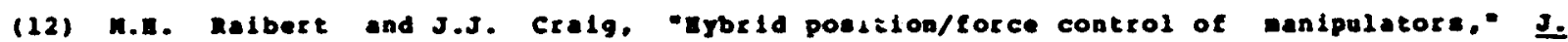
Dynenic Syctens, Measurenent, Control. June, 1961. P. 126.

(13) W.A. Perkins, -A Model sesed vision sjeten for Induetrial parts." ImE Trans. 으 Copputere. vol. C-27, 1976, p. 126.

(14) G.L. Gleason, G.J. Agí, -A Modular vision syeten for sensor-controlled Manipulation and Inspection." Proc. gth Int. Syeposiue on Industrial nobote. 1979, P. 37.

(15) M.R. Ward, et.al., consigat an Adaptive nobot witb vision, Robotice rodar, 1979. p. 26.

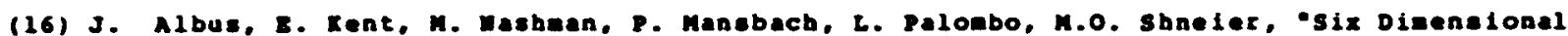
Vision Systen, SPIE, Vol. 336, Robot Vision, 1982, p. 142.

(17) R.C. Bolles, R.A. Cain, -aecognizing and Locating partially visible objectse The Local Feature-pocus Method, Int. Journal of lobotics zesearch. Vol. 1, 1982. p. 57.

(18) M.C. Bolles, P. Boraud, M.J. Manah, - jopos rbrec Dimensional parts orientation

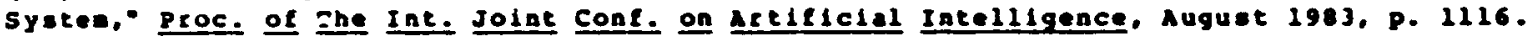

(19) J.A. Sippson, R.J. Eocken, J.8. Albue, The Automated nanufacturing Researcb Facility of the llational Burcau of standarda," Journal of Mapufacturing syetel, vol. 1. Mo. 1. 1983, p. 17.

(20) R. buaia, Eepresenting sol1ds for a Real-gine lobot sensory syoten," proc. prolaete 1985. Peris. June 1985.

(21) M.O. Stneier, E.M. Kent, P. Mansbech, -nepresenting Workspece and Model rporledge for a Robot with mobile sensora. Proc. 7th Int. Conf. pattern Recognition. 1984. p. 199.

(22) M.o. Shneier, R. Lunia, E.M. Rent, Model based strategiel tor migb-Letel Robot vision,: CVGIP, Vol. 33, 1986, P. 293.

(23) A. Barr. I. Feigenbaun. Ihe Handbook of Artificial Intelligence, (Los altos, Willial Reutean, 1981$\}$. 


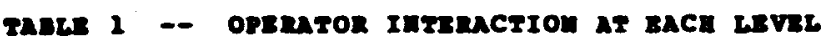

LETE

It the servo

ebove level 1

above level 2

above level 3

above level

above level 5

above level 6
TrTE OF InTEnaction

replice naster, Individual jolnt position, rate, or force controllers.

foy stick to perforn resolved notion force/rate control

Indicate eafe notion pathrays. Robot computes dyouncelly efficient morements

graphlcally or eyabolfcelly define key poese, enus to choose elemental noves.

epecley taske to be perforand on objecta.

reaselgn telerobote to different service bays. lneert, modify, and monitor plans describing eervicing takk sequences.

reconflgure serviclag miselon priorities. 


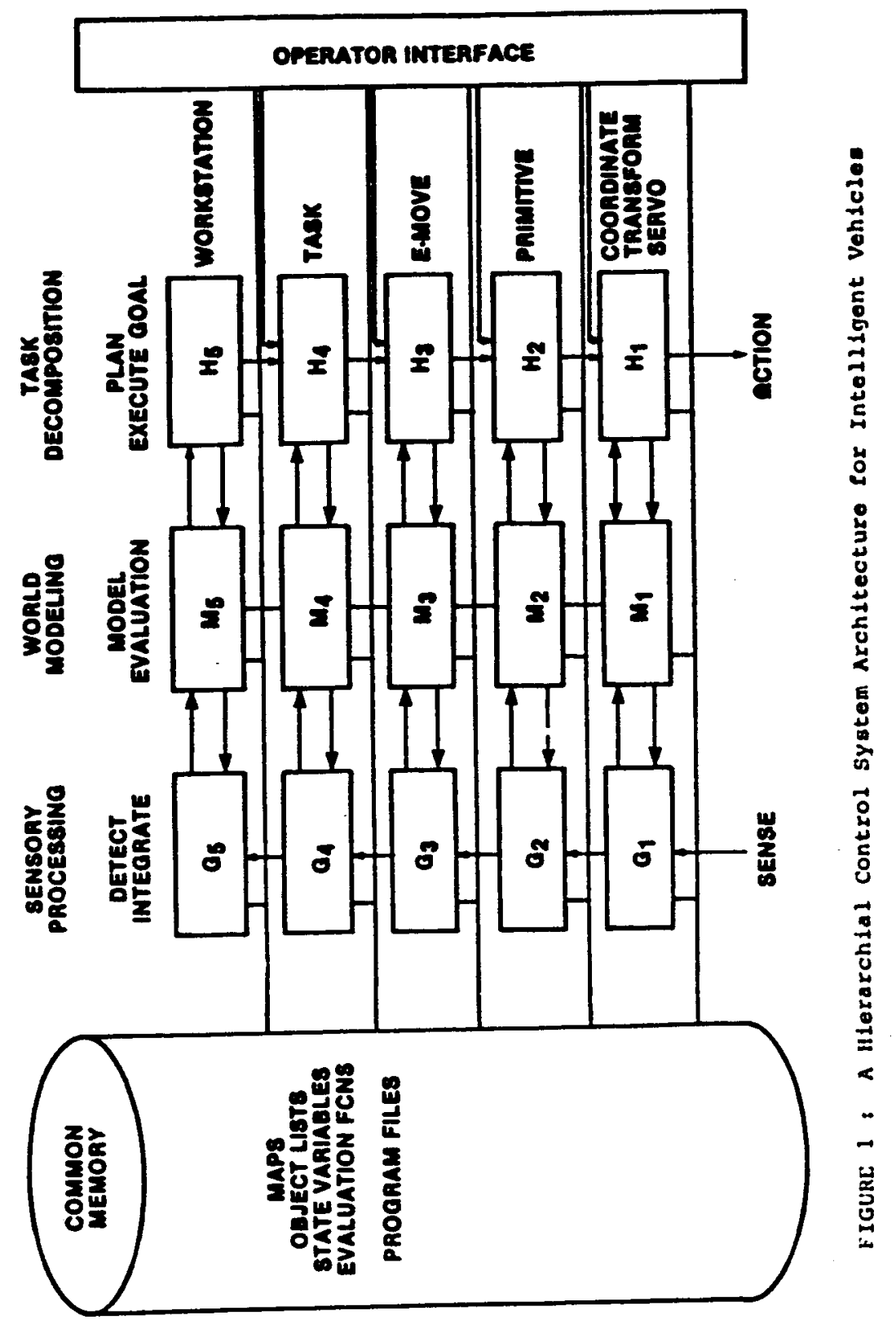



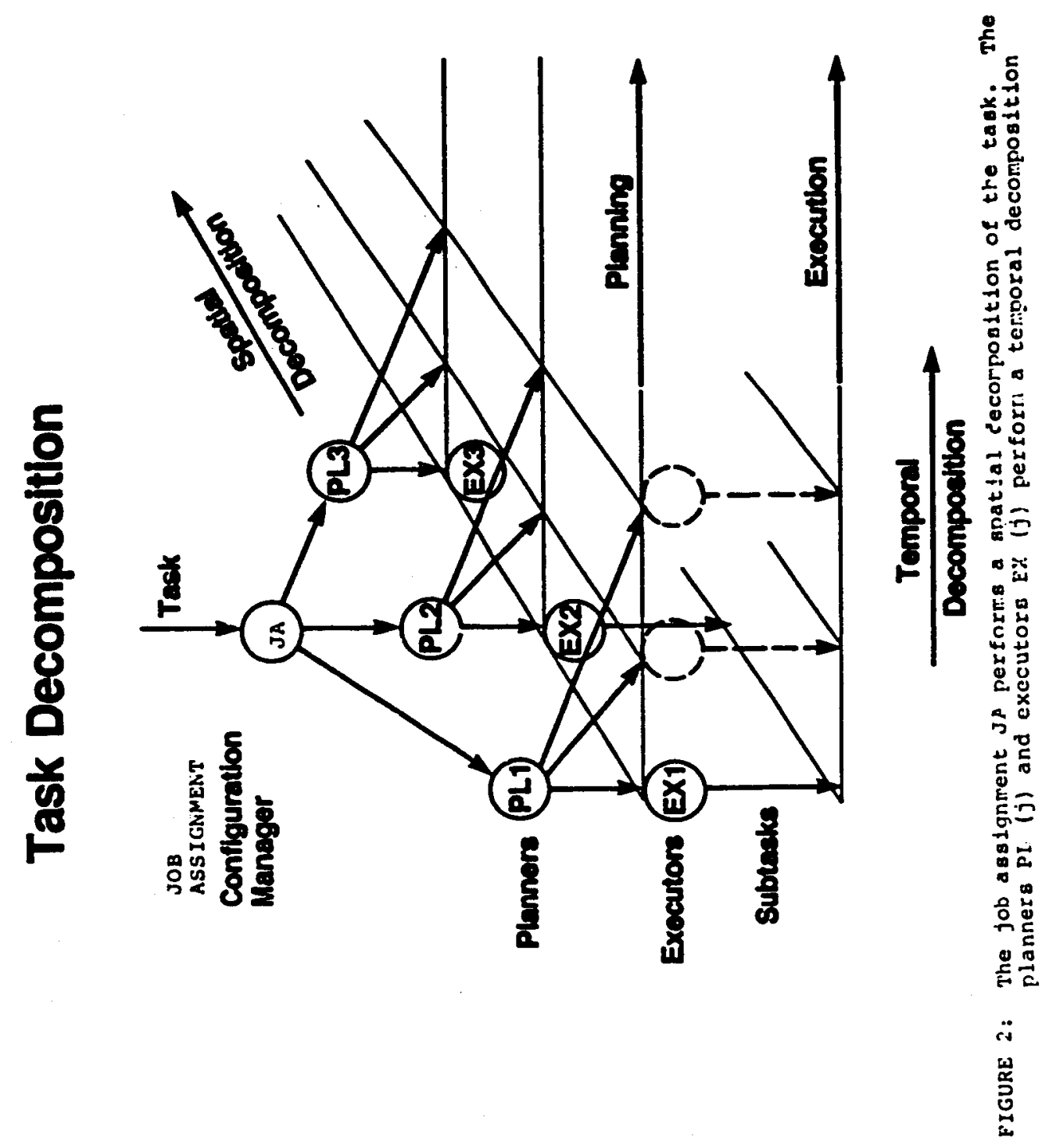


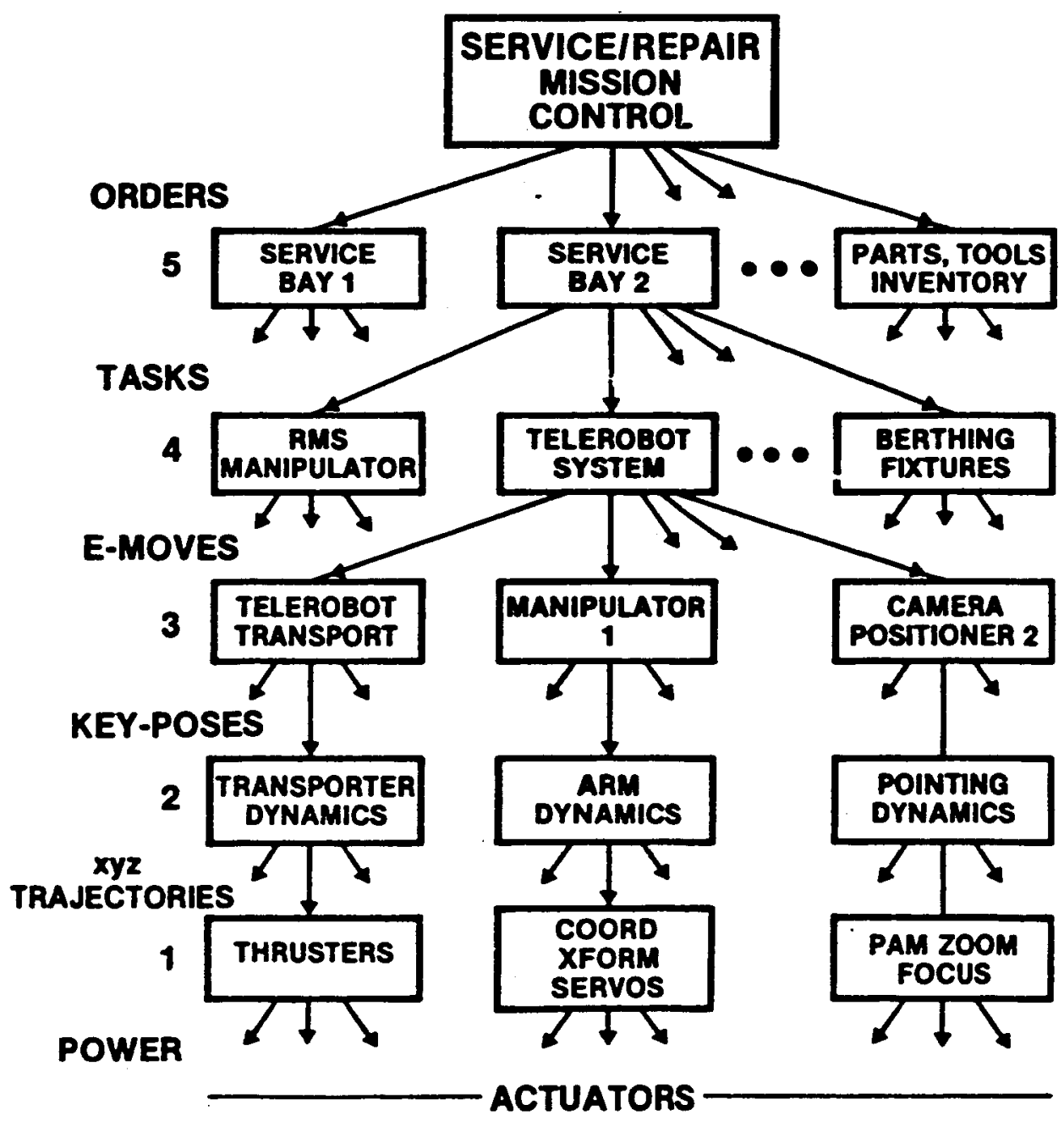

FICURE 3: A six level Fierarchial Control syster. Proposed for Multiole Autonomous Vehicles 


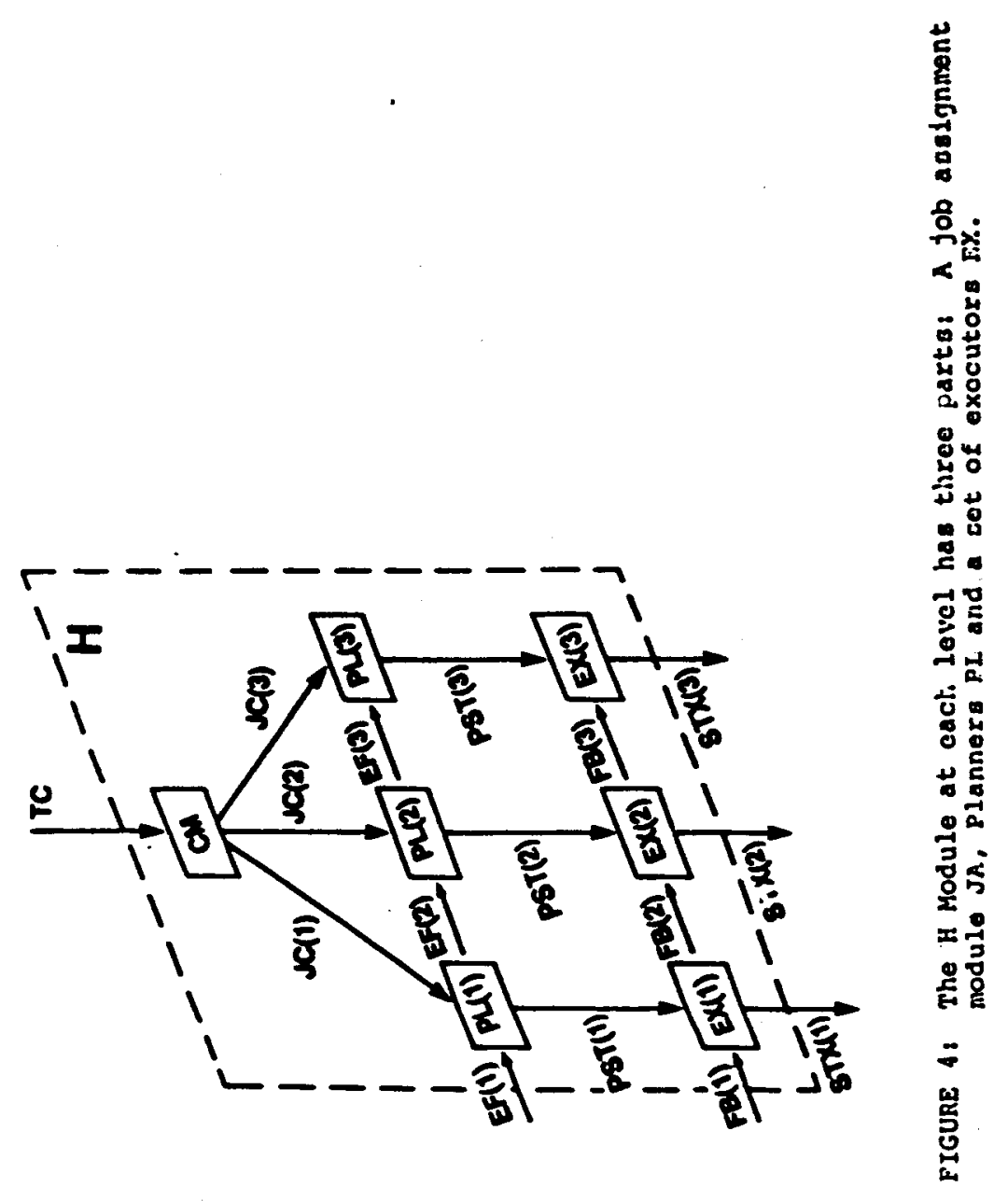

